INTERNATIONAL JOURNAL
OHARMACEUTICAL SCIENCES
PESEARCH
RESED

Received on 17 July 2019; received in revised form, 27 November 2019; accepted, 02 April 2020; published 01 May 2020

\title{
ANALYTICAL METHOD DEVELOPMENT AND VALIDATION FOR THE DETERMINATION OF MIRABEGRON IN PHARMACEUTICAL DOSAGE FORM BY RP-HPLC
}

Panchumarthy Ravi Sankar ${ }^{*}$, K. Purna Kishore ${ }^{1}$, B. Babji ${ }^{1}$ and Md. Shaheem Sulthana ${ }^{2}$

Department of Pharmaceutical Analysis 1, Vignan Pharmacy College, Vadlamudi, Guntur - 522213, Andhra Pradesh, India.

Department of Pharmaceutical Analysis ${ }^{2}$, ASN College of Pharmacy, Tenali - 522201, Andhra Pradesh, India.

Keywords:

Mirabegron, RP-HPLC method, Agilent technologies - 1260 infinity system, Validation, Limit of detection

\section{Correspondence to Author:}

Dr. Panchumarthy Ravi Sankar

Professor and HOD,

Department of Pharmaceutical

Analysis, Vignan Pharmacy College,

Vadlamudi, Guntur - 522213, Andhra

Pradesh, India.

E-mail: banuman35@gmail.com
ABSTRACT: This current study describes developing the novel, precise, simple analytical method suitable for determination of Mirabegron (MIRA) in a pharmaceutical dosage form. Reversed-Phase High-Performance Liquid Chromatography (RP-HPLC) method was utilized for method development and validation studies of MIRA. Chromatographic separation was carried out on Agilent technologies -1260 infinity system, eclipse XDB $\mathrm{C}_{18}$ column (4.6 $\mathrm{mm}$ i.d. $\times 250 \mathrm{~mm}, 5 \mu \mathrm{m}$ particle size) at a flow rate of $1 \mathrm{ml} / \mathrm{min}$ and detection wavelength set at $251 \mathrm{~nm}$. Mobile phase consists of methanol and acetonitrile were mixed in the ratio of 95:5 v/v. The retention time for MIRA was found to be $5.813 \mathrm{~min}$. The calibration was linear in the concentration range of $0.2-1.0 \mu \mathrm{g} / \mathrm{ml} .\left(r^{2}=0.999\right)$. The limit of detection and the limit of quantitation was found to be $0.0459 \mu \mathrm{g} / \mathrm{mL}$ and $0.1391 \mu \mathrm{g} / \mathrm{ml}$, respectively. The precision of the proposed HPLC method was found to be 0.06494 (RSD) for intraday and 0.135251 (RSD) for interday that indicates good precision of the sample MIRA analyzed. A recovery of MIRA in tablet formulation was observed in the range of $99.6-99.8 \%$. The percentage assay of MIRA (Betigma) was found to be $99.4 \pm 0.1$, respectively. The proposed method for MIRA was found to be accurate, precise, rapid, simple, and feasible for the estimation of MIRA in bulk as well as the pharmaceutical dosage form.
INTRODUCTION: The chemical name for Mirabegron is N-(4-(2-((R)-2-hydroxy-2-phenylethylamino) ethyl) phenyl) -2 - (2- aminothiazol-4yl) acetamide. MIRA is used for treating overactive bladder diseases and also cardiovascular stimulation ${ }^{1}$. Two randomized Phase I studies were conducted to evaluate the PK properties of Mirabegron ${ }^{2}$.

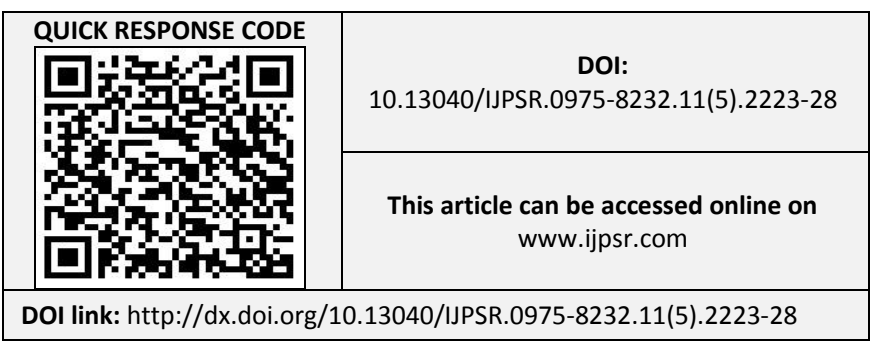

Recently, MIRA was shown to relax in-vitro human and rabbit prostate smooth muscle through activation of $\beta_{3}$ adrenoceptor. The same group also showed that MIRA promotes smooth muscle relaxation by $\alpha_{1}$ adrenergic receptor blockade ${ }^{3}$.

Excessive overconsumption of caffeine cause overactive bladder problems ${ }^{4}$. Absolute bioavailability ${ }^{5}$ is 29 or $35 \%$ following mirabegron dosages of 25 or $50 \mathrm{mg}$, respectively. Peak plasma concentrations achieved at approximately $3.5 \mathrm{~h}$ after oral administration. Steady-state concentrations achieved within 7 days of once-daily dosing. A literature survey revealed that very few analytical methods had been reported until now for the estimation of MIRA. 
The majority of methods for determination of MIRA in biological fluids and pharmaceutical dosage forms include LC-MS/MS ${ }^{6}$, RP-HPLC ${ }^{7-10}$, UV spectrophotometric ${ }^{11}$ analytical method is available in the literature for analyzing MIRA in pharmaceutical dosage form or as bulk drug sample. So far, to our present knowledge, only one RP-HPLC method was available. So, it is necessary to develop a simple, precise, and rapid RP-HPLC method for the quantitative determination of MIRA in the tablet dosage form. This current study describes the validation parameters stated by the International Conference on Harmonization [ICH] guidelines Q2 (R1) ${ }^{12-15}$. Fig. 1 shows the chemical structure of MIRA.

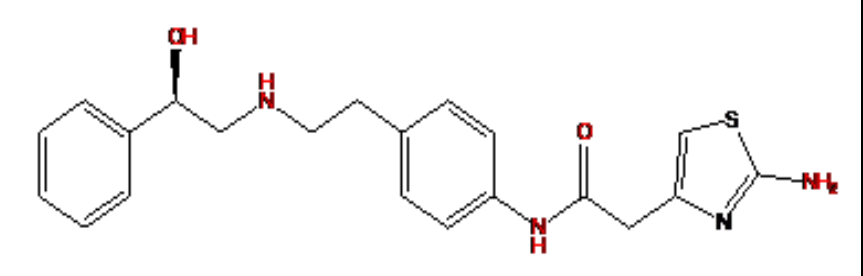

FIG. 1: CHEMICAL STRUCTURE OF MIRABEGRON

\section{MATERIALS AND METHODS:}

HPLC Instrumentation and Conditions: The experiments were conducted on Agilent technologies - 1260 infinity system, Eclipse XDB $\mathrm{C}_{18}$ column $(250 \mathrm{~mm} \times 4.6 \mathrm{~mm}$ i.d, particle size 5 $\mu \mathrm{m}$, maintained at ambient temperature). The mobile phase consisted of methanol: acetonitrile in the ratio 95:5 v/v. Isocratic elution at a flow rate of $1 \mathrm{ml} / \mathrm{min}$ at ambient temperature and using 1260 DAD VL detector to monitor the elute at $251 \mathrm{~nm}$.
To determine the optimum $\lambda_{\max }$, MIRA $10 \mathrm{mcg} / \mathrm{ml}$ of working standard solution was prepared and scanned in the UV wavelength range of $200-400$ $\mathrm{nm}$ utilizing $\mathrm{MeOH}$ as a blank. It was observed the drug showed maximum absorbance at $251 \mathrm{~nm}$, which was chosen as the detection wavelength for the estimation of MIRA. The UV overlain spectra of MIRA is shown in Fig. 2. The mobile phase was filtered through a $0.45 \mu \mathrm{m}$ nylon filter and degassed in ultra Sonicator prior to use.

Preparation of Mobile Phase: Prepare mobile phase composition of methanol and acetonitrile in required ratios, methanol, and acetonitrile were mixed in the ratio of $95: 5 \mathrm{v} / \mathrm{v}$ and was filtered through $0.45 \mu \mathrm{m}$ nylon membrane filter and degassed by sonication.

Preparation of Stock and Working Standard Solutions: Accurately $10 \mathrm{mg}$ of pure MIRA was weighed and transferred into a $10 \mathrm{ml}$ clean and dry volumetric flask, and the mobile phase was added, if necessary, sonicate to dissolve. The volume was brought up to the mark with the mobile phase. This is the primary stock solution of MIRA with a concentration of $1000 \mu \mathrm{g} / \mathrm{ml}$. A secondary stock solution is prepared by transfer $1 \mathrm{ml}$ of primary stock solution in $100 \mathrm{ml}$ volumetric flask and made up the mark with a mobile phase having the concentration $10 \mu \mathrm{g} / \mathrm{ml}$, again from this $5 \mathrm{ml}$ is poured into $50 \mathrm{ml}$ volumetric flask then the concentration would be $1 \mu \mathrm{g} / \mathrm{ml}$. Further dilutions were made to obtain the concentration in the range of $0.2-1.0 \mu \mathrm{g} / \mathrm{ml}$ of MIRA, respectively.

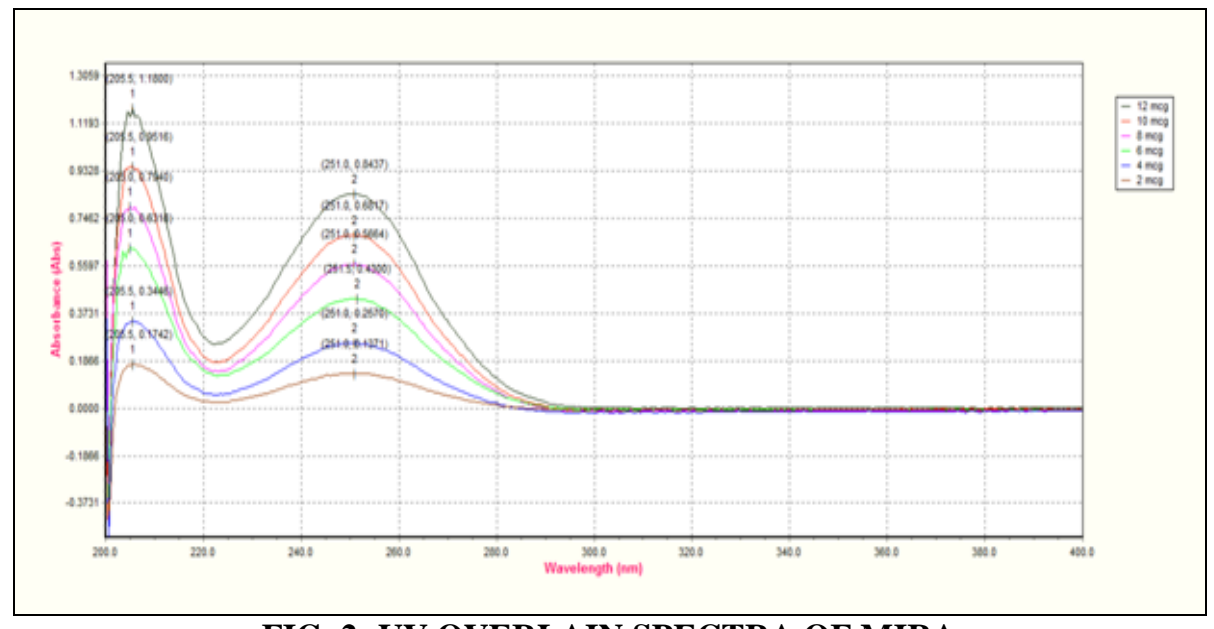

FIG. 2: UV OVERLAIN SPECTRA OF MIRA

Tablet Sample Preparation: For analysis in tablet dosage form, accurately weighed twenty tablets, and the average weight was calculated. Tablets were finely powdered, and the tablet powder 
equivalent to $10 \mathrm{mg}$ of MIRA was accurately weighed and transferred into a $100 \mathrm{ml}$ volumetric flask. The volume was filled up to mark with the mobile phase to the obtained concentration of 100 $\mu \mathrm{g} / \mathrm{ml}$. Further dilutions were made to the obtained concentration of $1 \mu \mathrm{g} / \mathrm{ml}$, and the solution was filtered using a $0.45 \mu \mathrm{m}$ nylon filter.

\section{RESULTS AND DISCUSSION:}

Optimization and Method Development: In order to acquire proper optimized HPLC conditions in the first occasion, several mobile phases, stationary phases, flow rates as well as $\mathrm{pH}$ of buffers were properly tested. Eventually, a mobile phase comprising of methanol and acetonitrile mixed in the ratio of 95:5 v/v and stationary phase made up of Eclipse $\mathrm{C}_{18}$ Column with $4.6 \times 250 \mathrm{~mm}, 5 \mu \mathrm{m}$ were observed, and they are found to be utmost suitable for analyzing MIRA.

The mobile flow rate and the detection wavelength were adjusted to $1 \mathrm{ml} / \mathrm{min}$ and $251 \mathrm{~nm}$, respectively at ambient column temperature. The summary of optimized chromatographic conditions for the proposed method is shown below in Table 1.

TABLE 1: OPTIMIZED CHROMATOGRAPHIC CONDITIONS FOR PROPOSED HPLC METHOD

\begin{tabular}{cc}
\hline Parameter & Chromatographic conditions \\
\hline Instrument & Agilent technologies -1260 Quat pump VL \\
Column & Eclipse XDB C 18 Column $(4.6 \mathrm{~mm}$ i.d. $\times 250 \mathrm{~mm}, 5 \mu \mathrm{m}$ particle size $)$ \\
Detector & Eclipse $1260 \mathrm{DAD}$ VL \\
Mobile phase & Methanol : Acetonitrile $(95: 5 \mathrm{v} / \mathrm{v})$ \\
Flow rate & $1 \mathrm{ml} / \mathrm{min}$ \\
Detection wavelength & $\mathrm{UV}$ at $251 \mathrm{~nm}$ \\
Run time & $10 \mathrm{~min}$ \\
Temperature & Ambient temperature $\left(25^{\circ} \mathrm{C}\right)$ \\
Volume of injection loop & $20 \mu 1$ \\
Retention time $\left(\mathrm{R}_{\mathrm{t}}\right)$ & $5.813 \mathrm{~min}$ \\
\hline
\end{tabular}

Method Validation: Once the chromatographic and the experimental conditions were established, the method was validated by the determination of the following parameters: specificity, system suitability, linearity, precision, accuracy, robustness, the limit of detection (LOD), limit of quantitation (LOQ), solutions stability following the ICH guidelines Q2 (R1).

System Suitability (SST): System suitability test was useful to a representative chromatogram to check the different parameters such as retention time, theoretical plates, and tailing factor. The system suitability test results for the proposed method are shown in Table 2. Thus, the system meets suitable criteria.

TABLE 2: SYSTEM SUITABILITY TEST RESULT FOR MIRA

\begin{tabular}{cccc}
\hline S. no. & Parameters & Results & \% RSD* \\
\hline 1 & Retention time & $5.813 \mathrm{~min}$ & 0.12 \\
2 & Theoretical plates & 11195 & 0.35 \\
3 & Peak area & 117825 & 0.25 \\
4 & Theoretical plates & $2,12,705$ & 0.35 \\
& per meter [t.p/m] & & \\
5 & Tailing factor & 1.112 & 0.16 \\
5 & Resolution & - & - \\
\hline
\end{tabular}

$*$ = Average of 5 determinations, $\%$ RSD $=$ percentage relative standard deviation

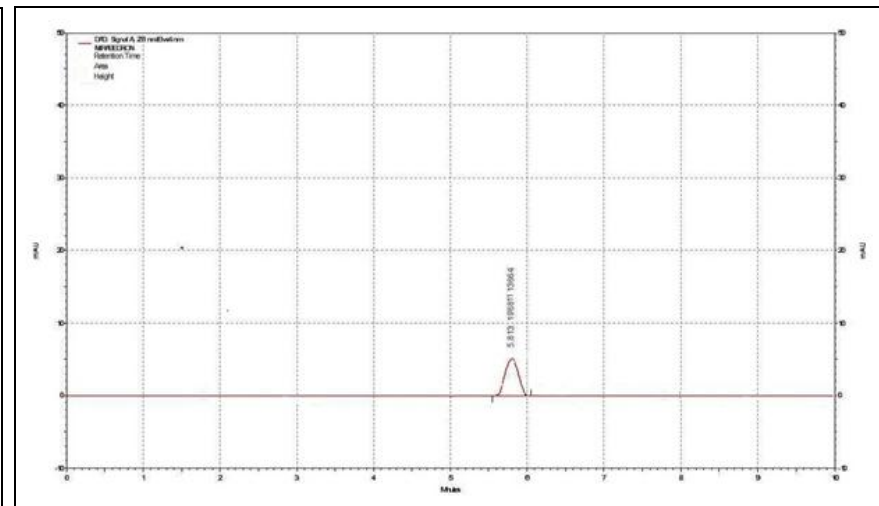

FIG. 4: CHROMATOGRAM OF MIRA SYNTHETIC DRUG 
Specificity: The accessibility of method specificity was determined by juxtaposing the chromatograms got from MIRA and blank solution. By mixing the most routinely utilized excipients in the mobile phase devoid of the drug. Fig. 3 and Fig. 4 shows the chromatograms of the blank as well as a synthetic drug, respectively.

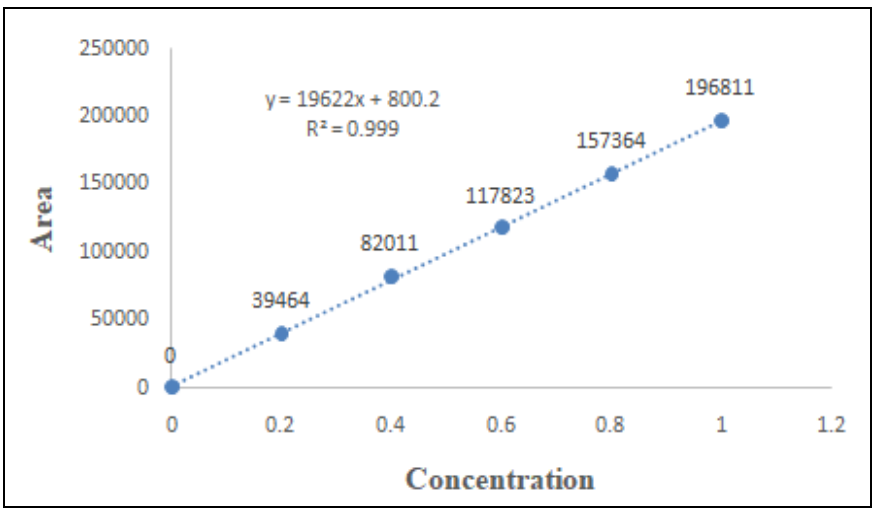

FIG. 5: CALIBRATION GRAPH OF MIRA BY RP- HPLC

Linearity: A series of solutions $(0.2-1.0 \mu \mathrm{g} / \mathrm{ml})$ were prepared from the MIRA stock solution, and $20 \mu \mathrm{l}$ of each solution was injected into the HPLC system and the peak area of the chromatogram was noted. A calibration curve was plotted by taking the concentration of the solutions on the $\mathrm{x}$-axis and the corresponding peak area values on the $y$-axis.
The calibration curves were constructed by plotting absorbance versus concentration, and the linearity was calculated by the least square regression method. A calibration curve is shown in Fig. 5. The linearity of response for the MIRA standard was estimated in the range of $0.2-1.0 \mu \mathrm{g} / \mathrm{ml}$. The correlation coefficient was found to be 1 . Therefore the HPLC method was found to be linear.

Precision: The precision of the method was determined by repeatability (intra-day) and intermediate precision (interday). Repeatability was determined by performing six repeated analysis of the same working solution of MIRA on the same day, under the same experimental conditions. The intermediate precision of the method was assessed by carrying out the analysis on different days and also by another analyst performing the analysis in the same laboratory (between-analysts). It was noted that the \% RSD values of precision for intraday and inter-day precision was 0.06494 and 0.135251 , respectively. Intra-day and inter-day \% values lower than $2 \%$ lucidly, assuring that this method was found to be fairly precise and reproducible. Precision results are tabulated in Tables 3 and 4.

TABLE 3: INTRA-DAY PRECISION

\begin{tabular}{ccccccc}
\hline \multicolumn{7}{c}{ Intra-day precision } \\
\hline S. no. & Sample name & Ret. Time & Area & Theoretical plate & Tailing Factor & Assay \\
\hline Average* $^{*}$ MSD* & MIRA & 5.813 & 117834 & 10915 & 1.15 & 100.12 \\
MIRA & 0.10 & 0.0649 & 0.41 & 0.28 & 0.13 \\
\hline
\end{tabular}

*Average of six determinations

TABLE 4: INTER-DAY PRECISION

\begin{tabular}{ccccccc}
\hline \multicolumn{7}{c}{ Inter-day precision } \\
\hline S. no. & Sample name & Ret. Time & Area & Theoretical plate & Tailing Factor & Assay \\
\hline Average* & MIRA & 5.813 & 117716 & 10815 & 1.23 & 99.421 \\
\% RSD* & MIRA & 0.11 & 0.135251 & 0.58 & 0.29 & 0.12 \\
\hline
\end{tabular}

*Average of six determinations

Accuracy: Accuracy of a method is defined as the closeness of a measured value to the true value. The recovery studies were carried out at 50\%, $100 \%$, and $150 \%$ levels of test concentration were prepared and injected into the HPLC system as per methodology. Table 5 shows the accuracy results of MIRA.

TABLE 5: ACCURACY STUDY

\begin{tabular}{ccccc}
\hline $\begin{array}{c}\text { Amount of the sample } \\
\text { added }(\boldsymbol{\mu g} / \mathbf{m l})\end{array}$ & $\begin{array}{c}\text { Amount of standard drug } \\
\text { solution added }(\boldsymbol{\mu g} / \mathbf{m l})\end{array}$ & Concentration & $\begin{array}{c}\text { Mean Percent } \\
\text { recovery }\end{array}$ & \% RSD* \\
\hline 0.6 & 0.3 & $50 \%$ level & 99.7 & 0.11 \\
0.6 & 0.6 & $100 \%$ level & 99.8 & 0.09 \\
0.6 & 0.9 & $150 \%$ level & 99.6 & 0.13 \\
\hline
\end{tabular}

*Average of triplicate injections 
Acceptance Criteria: The \% recovery values should be in the range of $98 \%-102 \%$ with \% RSD NMT 2.0.

Robustness: The robustness of an analytical procedure is the measure of its capacity to remain unaffected by small but deliberate variations in method parameters and provides an indication of its reliability during normal usage. For the determination of a method's robustness, parameters such as variation in detector wavelength are varied within a realistic range, and the quantitative influence of the variables is determined. If the influence of the parameter is within a previously specified tolerance, the parameter is said to be within the method's robustness range. The absorbance was measured, and the assay was calculated for six times. The results of robustness are presented in Table 6. There were no significant changes in the chromatographic pattern when the above modifications were made in the experimental conditions, showing thus that the method is robust.

Acceptance Criteria: The \% RSD of MIRA should be not more than $2.0 \%$.

TABLE 6: ROBUSTNESS RESULTS OF MIRA

\begin{tabular}{|c|c|c|c|c|c|c|c|}
\hline S. no. & Parameter & Optimized & Used & $\begin{array}{c}\text { Retention } \\
\text { time }\left(t_{R}\right), \text { min }\end{array}$ & $\begin{array}{c}\text { Plate } \\
\text { count }^{\$}\end{array}$ & $\begin{array}{c}\text { Peak } \\
\text { asymmetry }^{\#}\end{array}$ & Remark \\
\hline 1 & $( \pm 0.2 \mathrm{ml} / \mathrm{min})$ & $\mathrm{ml} / \mathrm{min}$ & $1.0 \mathrm{ml} / \mathrm{min}$ & 5.813 & 10,915 & 1.25 & *Robust \\
\hline \multirow[t]{3}{*}{2} & Detection wavelength & & $246 \mathrm{~nm}$ & 5.813 & 10,918 & 1.250 & Robust \\
\hline & $( \pm 5 \mathrm{~nm})$ & $251 \mathrm{~nm}$ & $251 \mathrm{~nm}$ & 5.812 & 10,915 & 1.25 & Robust \\
\hline & & & $256 \mathrm{~nm}$ & 5.813 & 10,916 & 1.25 & Robust \\
\hline \multirow{2}{*}{3} & composition & & $95: 05 \mathrm{v} / \mathrm{v}$ & 5.813 & 10,915 & 1.25 & *Robust \\
\hline & (Acetonitrile: Methanol) & & $90: 10 \mathrm{v} / \mathrm{v}$ & 5.869 & 10,940 & 1.202 & *Robust \\
\hline
\end{tabular}

Acceptance criteria (Limits): ${ }^{\#}$ Peak asymmetry $<1.5,{ }^{\$}$ Plate count $>2000, *$ Significant change in retention time

LOD and LOQ: Limit of Detection is the lowest concentration in a sample that can be detected but not necessarily quantified under the stated experimental conditions. The limit of quantitation is the lowest concentration of an analyte in a sample that can be determined. LOD and LOQ were obtained from the slope and the standard deviation of the intercept from three calibration curves determined by a linear regression line as defined by ICH. The limit of detection and limit of quantitation were found to be $0.0459 \mu \mathrm{g} / \mathrm{ml}$ and $0.1391 \mu \mathrm{g} / \mathrm{ml}$, respectively. Table 7 shows the results of LOD and LOQ.
TABLE 7: LOD AND LOQ RESULTS OF MIRA

$\begin{array}{cc}\text { Limit of Detection (LOD) } & 0.0459 \mu \mathrm{g} / \mathrm{ml} \\ \text { Limit of Quantitation (LOQ) } & 0.1391 \mu \mathrm{g} / \mathrm{ml}\end{array}$

Analysis of Betigma Tablet Formulation: The developed and validated method was successfully applied for the determination of MIRA in their tablet dosage form. The assay result Table 8 shows that the amount of the drug was in excellent agreement with the labeled value of the formulation. The representative sample chromatogram of MIRA is shown in Fig. 6. Table 10 represents the summary of validation parameters.

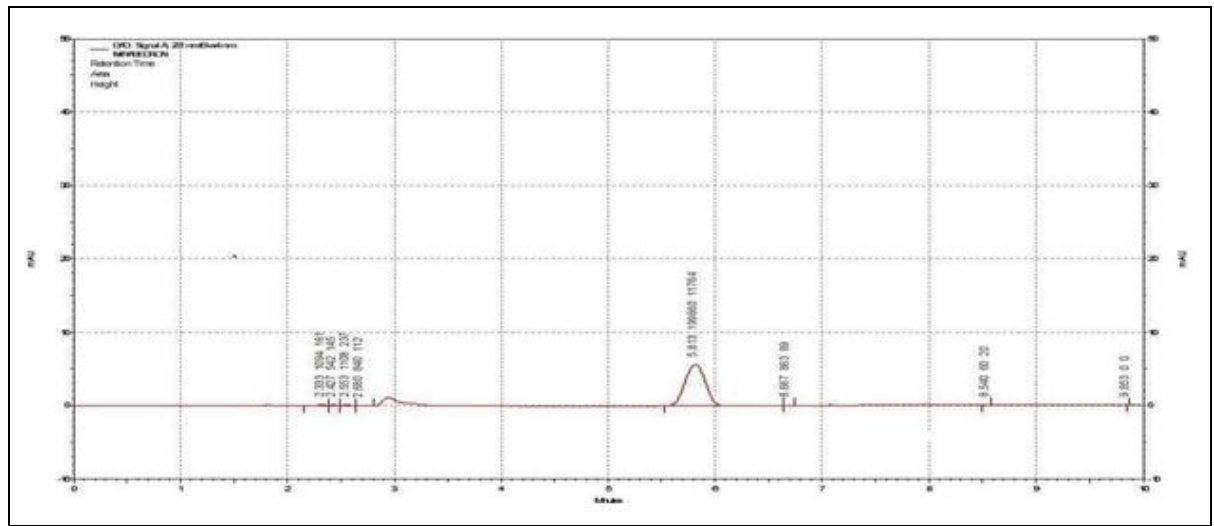

FIG. 6: MIRA SAMPLE CHROMATOGRAM (ASSAY) 
TABLE 8: ASSAY RESULTS OF MIRA

\begin{tabular}{ccccc}
\hline S. no. & Formulation & Labelled amount & Amount found & Mean \% Assay \pm SD \\
\hline 1 & Betigma tablets & $25 \mathrm{mg} /$ tablet & $24.85 \mathrm{mg} / \mathrm{tablet}$ & $99.4 \pm 0.1$ \\
\hline
\end{tabular}

*Average of six determinations. SD means standard deviation

\begin{tabular}{cc} 
TABLE 9: SUMMARY OF VALIDATION PARAMETERS \\
\hline Validation Parameters & Results \\
\hline Detection wavelength $\left(\lambda_{\max }\right)$ & $251 \mathrm{~nm}$ \\
Linearity range $(\mu \mathrm{g} / \mathrm{ml})$ & $0.2-1.0 \mu \mathrm{g} / \mathrm{ml}$ \\
Regression equation & $\mathrm{Y}=196224 \mathrm{x}+800.24$ \\
Correlation coefficient $(\mathrm{r})$ & 0.999 \\
Flow rate & $1 \mathrm{ml} / \mathrm{minute}$ \\
Retention time $\left(\mathrm{R}_{\mathrm{t}}\right)$ & $5.813 \mathrm{minutes}$ \\
Accuracy $(\%$ recovery) & $99.6-99.8 \% \mathrm{w} / \mathrm{w}$ \\
Intra-day Precision $(\% \mathrm{RSD})$ & 0.0649 \\
Inter-day Precision $(\% \mathrm{RSD})$ & 0.135251 \\
Limit Of Detection $(\mathrm{LOD}) \mu \mathrm{g} / \mathrm{ml}$ & $0.0459 \mu \mathrm{g} / \mathrm{ml}$ \\
Limit Of Quantification $(\mathrm{LOQ}) \mu \mathrm{g} / \mathrm{ml}$ & $0.1391 \mu \mathrm{g} / \mathrm{ml}$ \\
Assay $(\% \mathrm{w} / \mathrm{w})$ & $99.4 \% \mathrm{w} / \mathrm{w}$
\end{tabular}

CONCLUSION: In conclusion, the current research deals with the simple, sensitive, accurate, speed development and validation of an RP-HPLC method for estimation of MIRA in the pharmaceutical dosage form. The values of accuracy, precision, robustness, ruggedness, LOD, and LOQ were within limits. Statistical analysis for these results clearly demonstrates that the method is suitable for the determination of MIRA in tablet forms without any interference. In fact, the results of the assay of the pharmaceutical dosage form of the developed method were highly reproducible and reliable and also high-quality agreement with the label claim of the drug. From this study, it is concluded that this novel procedure RP-HPLC method for the determination of MIRA in a tablet formulation is convenient and effective for research studies, quality control, and routine analysis of MIRA in tablet dosage forms.

ACKNOWLEDGEMENT: The authors are thankful to Hetero Labs for providing the sample. We are highly grateful to Dr. L. Rathaiah, honorable chairman, Vignan Group of Institutions, Vadlamudi, Guntur for providing the necessary laboratory facilities to carry out the present investigation.

\section{CONFLICTS OF INTEREST: Nil}

\section{REFERENCES:}

1. Sacco E and Bientinesi R: Mirabegron a novel, nonantimuscarinic drug for overactive bladder. An up-to-date review. World J Obstet Gynecol 2013; 2: 65-73.

2. Krauwinkel W, Dijk JV, Schaddelee M, Eltink C, Meijer J and Strabach G: Mirabegron a $\beta 3$ - adrenoceptor agonist: results from two phase I, randomized, multiple-dose studies in healthy young and elderly men and women. Clinical Therapeutics 2012; 34: 2144-60.

3. Yamaguchi $\mathrm{O}$ and Chapple $\mathrm{C}$ : $\mathrm{R}$ : $\beta 3$ - adrenoceptors in urinary bladder. Neurourol Urodyn 2007; 26: 752-6.

4. Saputri F and Muchtaridi M: Analytical method development and validation for the determination of caffeine in green coffee beans $(C$. arabica L.) from three districts of West Java, Indonesia by high performance liquid chromatography. Int $\mathrm{J}$ Appl Pharm 2018; 10: 106.

5. Eltink $\mathrm{C}$, Lee $\mathrm{J}$ and Schaddelee $\mathrm{M}$ : Single dose pharmacokinetics and absolute bioavailability of mirabegron, B3- adrenoreceptor agonist for treatment of overactive bladder. Int J Clin Phar Ther 2012; 50: 838-49.

6. Teijlingen RV, Meijer J, Takusagawa S, Gelderen MV, Beld $\mathrm{CV}$ and Usui T: Development and validation of LC-MS/MS methods for the determination of mirabegron and its metabolites in human plasma and their application to a clinical pharmacokinetic study. J Chromator B Analyt Technol Biomed Life Sci 2012; 887-88: 102-11.

7. Ravisankar P, Shaheem Sultana, Mary Thanuja I, Dihitha Chowdary A and Vyshnavi J: Development and validation of a RP-HPLC method for the determination of Bamifylline hydrochloride in tablet dosage form. Int J Appl Pharm 2017; 9: 76-82.

8. Bhimanadhuni $\mathrm{CN}$ and Rao GD: RP-HPLC method for the determination of Mirabegron in Pharmaceutical dosage form. American J of Pharm Tech Res 2012; 2: 564-71.

9. Mounika B, Srikanth L and Venkatesha A: Determination and validation of RP-HPLC method for the estimation of mirabegron in tablet dosage form. IJCPR 2017; 9: 140-51.

10. Tabassum K and Sarvesh R: Analytical method development and validation studies of ticagrelor tablets by RP-HPLC. Int J Appl Pharm 2017; 9: 10-21.

11. Ravisankar P, Vidya VS, Nithya PD and Babu PS: Validated UV spectrophotometric method for quantitative determination of Mirabegron in bulk and Pharmaceutical dosage form. Der Pharmacia Lettre 2016; 8: 96-103.

12. Ravisankar P, Gowthami S and Rao GD: A review on analytical method development. Indian journal of Research in Pharmacy Biotechnology 2014; 2: 1183-95.

13. Ravisankar P, Navya CN, Pravallika D and Sri DN: A review on step-by-step analytical method validation. IOSR Journal of Pharmacy 2015; 5: 7-19.

14. ICH guidelines for validation of analytical procedures: text and methodology. Q2 (R1) ICH, Geneva 2005; 1-14.

15. Ravisankar P, Anusha S, Supriya $\mathrm{K}$ and Kumar UA: Fundamental chromatographic parameters. IJPSRR 2019; 55: 1183-95.

How to cite this article:

Sankar PR, Kishore KP, Babji B and Sulthana MS: Analytical method development and validation for the determination of mirabegron in pharmaceutical dosage form by RP-HPLC. Int J Pharm Sci \& Res 2020; 11(5): 2223-28. doi: 10.13040/IJPSR.0975-8232.11(5).2223-28.

All () 2013 are reserved by the International Journal of Pharmaceutical Sciences and Research. This Journal licensed under a Creative Commons Attribution-NonCommercial-ShareAlike 3.0 Unported License.

This article can be downloaded to Android OS based mobile. Scan QR Code using Code/Bar Scanner from your mobile. (Scanners are available on Google Play store) 